\title{
Editorial
}

\section{Ten years of publication in cell death}

\author{
DR Green ${ }^{1}$, RA Knight ${ }^{\star 2}$, G Melino ${ }^{3,4}$, A Finazzi-Agro'3 and \\ S Orrenius ${ }^{5}$ \\ 1 Division of Cellular Immunology, La Jolla Institute for Allergy and Immunology, \\ San Diego, CA, USA \\ 2 Department of Cystic Fibrosis, National Heart \& Lung Institute, Imperial \\ College, London SW3 6LR, UK \\ 3 Department of Experimental Medicine and Biochemical Sciences, University of \\ Rome 'Tor Vergata', Rome, Italy \\ ${ }^{4}$ MRC Toxicology Unit, University of Leicester, Leicester, UK \\ 5 Institute of Environmental Medicine, Karolinksa Institute, Stockholm, Sweden \\ * Corresponding author: RA Knight. Tel: + 44207351 8333; Fax + 44207351 \\ 8331; E-mail: r.a.knight@ic.ac.uk
}

Cell Death and Differentiation (2004) 11, 2-3. doi:10.1038/ sj.cdd. 4401355

Yes, dear readers, you have now followed us faithfully for 10 years!

It was in 1992 when we met in Erice in Sicily for an international meeting on cell death with 40 of the now most highly regarded experts in the field as lecturers, and only four other participants! Not discouraged by this rather limited interest, we decided that the time and market for a specialist journal were right, and undertook the conception of CDD. After a 20-months gestation worthy of an elephant, it is now 10 very short years since the birth of the journal, and we hope that in this time CDD has given you, our audience, as much pleasure to read, as it has us, as Editors, to administer. It is with enormous pleasure that we therefore introduce this special issue of CDD on the occasion of its 10th anniversary, and which is dedicated to Bob Horvitz in recognition of his monumental contribution to the field.

Although CDD is only a 10-year-old stripling, the field of cell death is much older. Some morphological observations, which we would now regard as descriptions of apoptosis, have been made since the middle of the 19th century, without their biological significance then being fully appreciated. In 1842, Vogt recognised that some cell death was physiological, while Flemming, in 1885, used the term chromatolysis to describe the nuclear fragmentation seen during this cell death - a characteristic still used, among others, as a hallmark of apoptosis. Occasional similar descriptions occurred later in the XIXth and early XXth centuries, and more recently the embryologist Gluckmann (1951), the haematologist Bessis (1955), and the biologist Tata (1960) clearly described distinct morphological phases of apoptosis. In the 1960s, working on insect development, Lockshin recognised the coordinated death of sheets of cells - a process he termed Programmed Cell Death - and which he showed to be energy dependent and to require gene transcription. In 1966, John Saunders, in his review on 'Death in embryonal systems', was able to emphasise the central role of cell death in moulding organisms during development. A little later, Kerr, Wyllie, and Currie described a similar cell death morphology in mammals, but this time affecting individual cells within a tissue, and for which they coined the term apoptosis. Thus, something like one and a quarter centuries had passed before the painstaking work of the early microscopists attained the dignity of scientific recognition and nomenclature. These developments have been elegantly recalled both in general ${ }^{1,2}$ or more specific ${ }^{3}$ manuscripts.

It was not, however, until apoptosis moved from the morphological to the mechanistic that it fully acquired scientific credibility and started to provide an intellectual framework for previously scattered observations. For this, the credit is largely due to Robert $\mathrm{H}$ Horvitz and his collaborators (Michael Hengartner and Junying Yuan). Working with the nematode, Caenorhabditis elegans, Sulston, Horvitz, and colleagues first mapped the fate of every cell in the organism, including those that were to commit apoptosis. Apart from its academic significance, this had important practical consequences in several disciplines of medicine.

When we first contacted Rita Levi-Montalcini, she was delighted to have the opportunity of returning to the field of cell death, a corner of science to which she herself had contributed, albeit in the field's prehistory. In 1942, Rita published a paper in the French journal Extrait des Archives de Biologie, ${ }^{4}$ which dealt with early ideas on the consequences of neurodegeneration in the developing chick embryo, a process now recognised as occurring via programmed cell death, and in which she describes the phenomena of ' .... atrophie très pronocée, caractérisée par la conglutination des neurofibrilles dans une masse homogène et par l'atrophie du noyau'. ${ }^{4}$ These observations led to the identification of trophic factors, as now well known, and in particular of nerve growth factor, for which Rita was awarded the Nobel Prize. It seemed particularly appropriate, therefore, to invite her to write the Welcome Address to this anniversary and celebratory issue.

In this special issue, we will devote particular attention to two applied aspects of apoptosis, cancer and neuroscience. Thus, some of the oncological implications are highlighted in the manuscripts of Alfred Knudson, ${ }^{5}$ George Klein, ${ }^{6}$ and Michael Hengartner, ${ }^{7}$ while the specific aspects of cell death in neuroscience are reviewed in the contributions from Stuart Lipton, ${ }^{8}$ Lloyd Greene, ${ }^{9}$ and Gene Johnson. ${ }^{10}$ These manuscripts are put in an evolutionary context by the analysis of Jean-Claude Ameisen. ${ }^{11}$

What better occasion, then, than this 10th anniversary, and what better venue than this, to award an Honorary Degree from the University of Tor Vergata to Bob Horvitz, to celebrate the ultimate recognition of the crucial importance of apoptosis in biology. For it was here, at Villa Mondragone in Rome in 1582, that Pope Gregorius XIII replaced the old inaccurate Julian (Caesarean) calendar by the still sun-based but far more reliable Gregorian version that we still use today.

As editors, and also as Rector of the University of Rome Tor Vergata (AFA), we are truly delighted to be able to gracefully present this special issue on this special occasion to the readers of CDD. 
1. Ameisen JC (1999) La sculpture du vivant. Ed. du Seuil Paris

2. Melino $G$ (2001) Nature 412: 23

3. Green DR, Droin N and Pinkoski M (2003) Immunol. Rev. 193: 70-81

4. Levi-Montalcini R and Levi G (1942) Extrait. Archiv. Biol. LIII: 536-545

5. Knudson AG (2004) Cell Death Differ. 11: 11-12

6. Klein G (2004) Cell Death Differ. 11: 13-17
7. Stergiou L and Hengartner M (2004) Cell Death Differ. 11: 21-28

8. Lipton SA and Chen HSV (2004) Cell Death Differ. 11: 18-20

9. Greene LA, Biswas SC and Liu DX (2004) Cell Death Differ. 11: 49-60

10. Putcha GV and Johnson Jr EM (2004) Cell Death Differ. 11: 38-48

11. Ameisen JC (2004) Cell Death Differ. 11: 4-10 